Chirurgia (2017) 112: 403-412

No. 4, July - August

Copyright $\odot$ Celsius

http://dx.doi.org/10.21614/chirurgia.112.4.403

\title{
Radiation Therapy Following Breast Conserving Surgery for Ductal Carcinoma in situ: Yes or No?
}

\author{
Liviu Sorin Stoleru', Smaranda Stoleru \\ 'Radiotherapy Department - Neolife Medical Center, Bucharest, Romania \\ 2Department of Pharmacology and Pharmacotherapy, "Carol Davila" University of Medicine and Pharmacy, Bucharest, Romania
}

Corresponding author:

Liviu Sorin Stoleru, MD

Neolife Medical Center

Bulevardul Ficusului 40, Bucharest

E-mail: liviu.stoleru@neolife.ro

\section{Abbreviations:}

BCS: Breast Conserving Surgery; BCSD: Breast Cancer Specific Death; DCIS: Ductal Carcinoma In Situ; HF: Hypofractionation;

IBTR: Ipsilateral Breast Tumor

Recurrences:

LR: Local Recurrence:

RT: Radiotherapy;

SLNB: Sentinel Lymph Node Biopsy;

\section{Rezumat}

Radioterapia după chirurgia conservatoare a sânului pentru carcinomul ductal in situ: da sau nu?

Carcinomul ductal in situ al sânului este un precursor non-invaziv al cancerului mamar şi este reprezentat de un grup de leziuni cu potential malign variabil. Tratamentul local optim pentru pacientele cu carcinom ductal in situ rãmane un subiect controversat, în ciuda rezultatelor provenite din mai multe trialuri randomizate. Radioterapia care urmeazã intervenției chirurgicale conservatoare reduce aproximativ la jumãtate riscul de recidivã localã, dar nu are impact în ceea ce priveşte supraviețiirea pe termen lung. Studiile clinice desfãşurate pânã în prezent nu au putut identifica un subgrup de paciente cu carcinom ductal in situ cu risc scãzut, la care sã se poata renunța în siguranțã la radioterapie, dupã intervenția chirurgicala conservatoare. În lucrare sunt prezentate rezultate ale studiilor clinice în care s-a utilizat chirurgia conservatoare a sânului urmatã sau nu de radioterapie. Alte subiecte abordate se referã la stabilirea indicației terapeutice în cazul carcinomului ductal in situ cu risc scãzut şi la noi tendințe în radioterapia pentru carcinomul ductal in situ.

Cuvinte cheie: carcinom ductal in situ al sânului, intervenție chirurgicalã conservatoare, radioterapie

\section{Abstract}

Ductal carcinoma in situ (DCIS) is a non-invasive precursor to 
breast cancerand represents a heterogenous group of lesions with different malignant potential. Despite several randomized trials, there is still controversy regarding the optimal local treatment for DCIS patients. The addition of radiotherapy after breast conserving surgery approximately halves the local recurrence risk but has no impact on long-term survival. Clinical studies failed to identify a low risk subgroup of DCIS patients treated with breast conserving surgery in whom radiotherapy can be safely omitted. Results of clinical trials of breast conserving surgery \pm radiotherapy are summarized. Treatment decision making in low risk DCIS and current tendencies in the radiotherapy for DCIS are other issues addressed in this paper.

Key words: ductal carcinoma in situ, breast conserving surgery, radiotherapy

\section{Introduction}

Ductal carcinoma in situ (DCIS) is a noninvasive precursor to breast cancer, characterized by increased epithelial proliferation, subtle to marked cellular atypia and an inherent but not necessarily obligatory tendency for progression to invasive breast cancer. (1)

Dissemination of screening mammography and advances in imaging allowing more cancer lesions to be spotted in early phases, resulted in a substantial increase in the frequency of DCIS.

It currently accounts for about $20-25 \%$ of newly diagnosed breast cancer. $(2,3,4)$

DCIS represents a heterogenous group of lesions with different malignant potential. Although it is considered preinvasive, not all lesions will progress to invasive breast cancer.

The risk of transformation to invasive carcinoma was approximately $40 \%$ in a group of patients with low grade DCIS treated with biopsy alone and followed for more than 30 years. All invasive lesions developed at the same site - in the same breast and quadrant from which their DCIS biopsy was taken. (5)

Invasive local recurrences carry a worse prognostic with a significant increase in all-cause and breast cancer mortality risk. $(6,7)$ Therefore, the main goal when treating DCIS is to minimize the risk of progression to invasive breast cancer.

Because the vast majority of recurrences occur in the breast itself rather than in regional or distant sites, selecting the most appropriate local treatment for each individual patient represents the mainstay of the therapeutic strategy. (8)

\section{Local Treatment Strategies}

According to the NCCN (9) local treatments include:

- Lumpectomy without lymph node surgery + whole breast radiotherapy (RT);

- Lumpectomy without lymph node surgery without RT;

- Total mastectomy with or without sentinel node biopsy \pm reconstruction.

Mastectomy was the reference treatment for DCIS with $1-2 \%$ rate of local recurrence (LR). (10)

General guidelines for the use of mastectomy in DCIS recommend that patients with extensive and/or multifocal DCIS involving 4-5 cm of disease or more than one quadrant should be offered mastectomy. $(9,10)$

In addition to these patients, women with potential contraindications to breast irradiation or a strong preference for mastectomy over breast conservation are considered appropriate candidates for this procedure. (10)

It is estimated that mastectomy is performed in approximately one third of DCIS cases. $(11,12,13)$

Complete axillary node dissection is not recommended in the absence of evidence of invasive breast cancer or proven axillary metastatic disease in patients with apparent pure DCIS or mammographically detected 
DCIS with microcalcifications.

Most women with DCIS do not require assessment of the axillary nodes, because DCIS is not invasive cancer and does not metastasize.

In patients with seemingly pure DCIS to be treated with mastectomy or with excision in an anatomic location (eg. tail of the breast), which could compromise the performance of a future sentinel lymph node biopsy (SLNB), a SLNB may be considered. (9)

Although it cures almost all patients, mastectomy is considered overtreatment in many cases, especially when there are small radiologically detected lesions.

Most women are eligible for breast conserving surgery (BCS) and therefore, a major decision is whether to add postoperative radiotherapy.

In the early nineties, four prospective randomized trials were conducted to clarify the role of postoperative RT in patients with DCIS (Table 1)

Rates of LR at median follow-up intervals of approximately 13 to 17 years ranged from 23\% to $35 \%$ in BCS alone compared with $9 \%-20 \%$ in the BCR +RT arms.

About half of the recurrences were invasive cancers that can potentially metastasize and require toxic systemic therapies as part of salvage therapy.

Although RT has been proven to halve the risk of LR, this reduction has no impact on survival.
Postoperative RT halves the LR risk after BCS alone with similar effects in reducing the risk of subsequent "in situ" and invasive LR. $(6,7,14,15)$

The Early Breast Cancer Trialists Collaborative Group (EBCTG) meta-analysis performed on 3,729 patients enrolled in these four randomized trials showed that $\mathrm{RT}$ reduced the absolute $10^{-}$year risk of any ipsilateral breast event (either recurrent DCIS or invasive cancer) by $15.2 \%$, from $28.1 \%$ to $12.9 \%$ (2 $\mathrm{p}<0.0001)$

Its effectiveness does not differ significantly in relation to age, extension of the surgical procedure (lumpectomy vs quadranectomy), tamoxifen use, diagnosis method (radiological or clinical), margin status (free, close or unknown) nuclear grade, presence of comedonecrosis, architectural subtype and tumor size.

Even for 291 women with low risk (negative margins and small low grade tumorous) the absolute reduction in the 10-year risk of ipsilateral breast events was $18 \%$ (12.1 vs $30.1 \% ; 2 \mathrm{p}>0.002$ ).

After 10 years of follow-up, there was however no significant effect on breast cancer mortality, mortality from causes other than breast cancer (i.e. cardiac mortality) or all cause of mortality. (16)

Given that there were only 3,729 eligible patients in the meta-analysis, the ability to detect a hypothetical gain in survival by

Table 1. First-Generation Randomized Trials Comparing Lumpectomy With and Without Radiation Therapy (modified from 22)

\begin{tabular}{|c|c|c|c|c|c|c|c|c|c|}
\hline \multirow[t]{2}{*}{ Trial } & \multirow[t]{2}{*}{$\begin{array}{l}\text { Dates of } \\
\text { Accrual }\end{array}$} & \multirow[t]{2}{*}{$\begin{array}{c}\text { Evaluable } \\
\text { Patients } \\
\text { (No.) }\end{array}$} & \multirow[t]{2}{*}{$\begin{array}{l}\text { Median } \\
\text { Follow-Up } \\
\text { (years) }\end{array}$} & \multicolumn{2}{|c|}{$\begin{array}{c}\text { Local Failure } \\
\text { Rate (\%) }\end{array}$} & \multicolumn{2}{|c|}{$\begin{array}{l}\text { Distant Failure } \\
\text { Rate (\%) }\end{array}$} & \multicolumn{2}{|c|}{$\begin{array}{c}\text { Breast Cancer } \\
\text { Mortality Rate } \\
(\%)\end{array}$} \\
\hline & & & & No RT & RT & NoRT & RT & No RT & RT \\
\hline NSABP B-17 & $1985-1990$ & 813 & 17.25 & $35^{\star}$ & 20 & - & - & $3{ }^{\prime} \mathrm{H}$ & 5 \\
\hline EORTC10853 & $1986-1996$ & 1,010 & 15.80 & $31^{\prime} \mathrm{H}$ & 18 & 9 & 10 & $4^{*}$ & 5 \\
\hline SweDCIS & 1987-1999 & 1,046 & 17.00 & $32^{\circ}$ & 20 & 3 & 4 & $4^{\circ}$ & 4 \\
\hline United Kingdom-Australia-New Zealand & 1990-1998 & 1,030 & 12.70 & $23^{*}$ & 9 & - & - & $3^{*}$ & 2 \\
\hline EBCTG Meta-Analysis & - & 3,729 & 8.90 & $28^{\S}$ & 13 & - & - & $4^{\S}$ & 4 \\
\hline
\end{tabular}

Abbreviations: DCIS, ductal carcinoma in situ; EBCTCG, Early Breast Cancer Trialists' Collaborative Group; EORTC, European Organization for Research and Treatment of Cancer; NSABP, National Surgical Adjuvant Breast and Bowel Program; RT, radiation therapy; SweDCIS: Swedish DCIS trial.

*Crude rate. ${ }^{\circ}$ H15-year actuarial rate. ${ }^{\circ} 20$-year actuarial rate. ${ }^{5} 10$-year actuarial rate 
adding RT to BCS is underpowered and only a very large randomized clinical trial or metaanalysis could have sufficient statistical power to detect a survival benefit, if any, from adding radiation after BCS. $(17,18)$

The absence of an effect on cardiac mortality with RT is especially important when evaluating a patient with left side DCIS, because in assessing the risks versus the benefits of adding RT, complications from RT, including a hypothetical adverse impact on cardiac events, have been proposed as a rationale not to give RT after lumpectomy. $(19,20,21)$

However, these studies are characterized by some limitations mainly related to the pathological assessment, which was not standardized (i.e. - tumor size measurement, free margins definition).

Additionally, selection criteria were broad with regard to patient age at diagnosis, the means of presentation (mammographically detected or symptomatic), lesion size and histologic features. (22)

\section{Prognostic Factors and Selection of "Good Risk" Patients}

Risk factors usually associated with LR are patient age, tumor size, tumor grade and margin width. (9)

\section{Young Age}

Young age (generally under 40 to 50) is an independent risk factor for LR after BCS with or without RT for DCIS. The reasons for significant higher LR rates in young women remain uncertain in the absence of a clear impact of both histopathological factors (high grade, multicentricity, margin status) and treatment related factors modalities (probably less extensive surgery in order to ensure a better cosmetic outcome). $(23,24)$

\section{Tumor Size}

Although tumor size is generally regarded as an important indicator of LR, DCIS size is sometimes difficult to assess, due to the uncertainties linked to the exact relevance of mammographic micro-calcifications and discontinuous growth pattern. (25)

In a recent report of Alvarado et al on 2,037 patients with a diagnosis of pure DCIS treated between 1996 and 2009, tumor size was a significant prognosticator, with 5-year $\mathrm{LR}$ rates of $5.6 \%$ vs $2.2 \%$ for lesions over and under $15 \mathrm{~mm}$ respectively. (26)

\section{Nuclear Grade}

In a review of the randomized and observational studies between 1970to 2009, women with high vs low grade of tumor had a 104\% increase in odds of IBTR. Comparison of intermediate vs low grade were much less consistent. (27)

The impact of DCIS grade on LR risk appears to be related to the length of follow-up. In a study of Solin et al, patients with comedoarchitecture and nuclear grade 3 had a significantly higher 5-year LR rate; the difference was no longer statistically significant at 10 years. (28)

In the EORTC trial multivariate analysis at a median follow-up of 10.5 years, intermediately or poorly differentiated DCIS had a significantly increased risk for LR as opposed to well differentiated DCIS ( $\mathrm{HR}=1.85$ and HR $=1.61$ respectively). (29)

In the updated multivariable analysis performed at 15 years, nuclear grade was not an independent risk factor for local recurrence. (7)

\section{Margins}

Although multiple retrospective and prospective clinical trials have shown that obtaining negative margins is associated with a decreased rate of LR, until recently there has been a lack of consensus on what represents adequate negative margins in DCIS.

As a consequence, approximately one in three women treated for DCIS undergoes a reexcision. (30) Re-excisions have the potential for added discomfort, surgical complications, compromise in cosmetic outcomes, additional stress for patients and families and increased health care costs and have also been associated with conversion to bilateral mastectomy. (31)

The Society of Surgical Oncology (SSO), American Society for Radiation Oncology 
(ASTRO) and the American Society of Clinical Oncology (ASCO) developed a Consensus Guideline on margins for BCS with wholebreast radiotherapy (WBRT) in DCIS. (32)

The guideline was based on the results of a meta-analysis including 20 studies, 7,883 DCIS patients with known margins status and 865 ipsilateral breast tumor recurrences (IBTR).

\section{Selection of "Good Risk" Patients}

Although RT has been proven to halve the risk of LR, this reduction did not translate into a survival benefit. $(6,7,14,15,16)$

Overall, mortality from DCIS is low, regardless of chosen treatment, with 10-year risk of death as a result of invasive breast cancer ranging from 1.0 to $2.6 \%$. (33)

Cumulative breast cancer specific death (BCSD) incidence at 20 years was $4.1 \%$ in the $\mathrm{RT}$ arm and $4.2 \%$ in the control arm in the randomized SweDCIS Trial. (14)

The lack of survival benefit from adding adjuvant $\mathrm{RT}$ and the small, but real potential risk of adverse effects (34) are reasons commonly given to omit RT after BCS for DCIS. The risk-benefit ratio may favor skipping adjuvant treatment if a cohort of patients could be prospectively identified at presentation with a sufficiently low risk of recurrence after surgical excision alone. (35)

Silverstein et al proposed the Van Nuys Prognostic Index based on pathological characteristics (grading and comedonecrosis), size and margins. Patients were stratified using a three-point score for each predictor. (36)

In 2003 age was added to this prognostic score; < 39 years of age (high score), 40-60 years of age (intermediate score) and $<61$ years of age (low score).

To patients with a low score (from 4 to 6) BCS alone was recommended, to those with intermediate score (from 7 to 9) BCS + post-operative $\mathrm{RT}$ and to those with a high score - mastectomy since the LR incidence at 5 years appeared too high - around 50\% with BCS + RT. (37)

Based on a retrospective analysis, this score has not been validated by other researchers. $(38,39)$

The inclusion criteria of the RTOG 9804 study - mammographically detected DCIS, low or intermediate grade, $\leq 2.5 \mathrm{~cm}$ in size, resected margins negative at a minimum of $3 \mathrm{~mm}$ - now serve as the gold standard for defining low risk DCIS. (40)

RTOG 9804 was a prospective randomized trial comparing $\mathrm{RT}$ with observation after BCS in patients with low risk DCIS. Although the study was designed for 1,790 patients, it was closed early because of lower than projected accrual with only 636 patients enrolled. (41)

The ECOG-ACRIN E5194 Study was a prospective study of patients selected for low risk clinical and pathologic characteristic who received BCS without RT. (35)

Importantly, this study demonstrated a continued increase without plateau in the rate of LR after BCS alone, failing to identify a good risk cohort of patients with DCIS for whom RT can be safely omitted. (35)

Similarly, the eight-year update of another prospective trial of wide excision alone for small (tumor size $\leq 2.5 \mathrm{~cm}$ mammographically) predominantly low or intermediate grade DCIS demonstrated a 10-year local recurrence rate of $15.6 \%$ (1.9\% per patient year), despite widely negative margins $(\geq 1 \mathrm{~cm})$. (42)

Because the risk of developing a LR after surgical excision is not well defined by clinical and pathological characteristics, more recent efforts have focused on using tumor genetics to determine the risk of recurrence after local excision.

The Oncotype DX, DCIS score calculated from seven cancer related genes and five reference genes, independently predicts the risk of LR and provides a new clinical tool for treatment decision making. $(43,44)$

Prospective studies are still required to validate the potential of such tests, particularly due to the costs associated with this use (45).

\section{Radiation Therapy Decision Making}

The first important point particularly for older 
patients with low risk DCIS, as defined by the inclusion criteria of RTOG 9804 is to evaluate the functional status and associated significant comorbidities.

Given that IBTR risk without RT is only $3.5 \%$ in the first five years, a high likelihood of death within 5 years could be an argument to omit RT in these patients. (40)

Anticipated risk of $\mathrm{RT}$ should be carefully weighed for every patient.

Although RT is generally well tolerated with the new conformal techniques, there are certain situations in which the radiation induced toxicity for the skin and soft tissues may be important. The risk-benefit ratio for this kind of patients does not favor postoperative RT. (40)

A left sided DCIS, with a high anticipated cardiac dose in patients with cardiac risk factors or known diseaserepresents another clinical scenario where omission of $\mathrm{RT}$ is advisable, especially when cardiac sparing techniques (deep-inspiration breath hold technique, prone position technique) are not available.

Patients with large and pendulous breasts are difficult to position for $\mathrm{RT}$ and are prone to higher risks of acute skin toxicity and fibrosis, even when high conformal techniques are used. $(46,47)$

It is also important in what terms clinicians use to describe DCIS. Many women are unable to distinguish between preinvasive and invasive cancer and often overestimate the implications of a DCIS diagnosis (48) and the risk of a breast cancer recurrence or death after treatment. $(49,50)$ These misperceptions may drive willingness for more extensive treatments. (51)

The type of salvage treatment needed for LR if the patient comes to develop a LR should also be discussed with the patient. (40)

One of the arguments in favor of omitting RT after BCS is the hypothetical ability to repeat a breast conservative approach.

About $50 \%$ of the patients are eligible for this type of salvage treatment (7), but many reject BCS favoring mastectomy because they are too traumatized psychologically to be willing to face another possible local recurrence. (22)

Breast preservation after a second BCS could be offered with a reasonable cosmetic outcome in women with relatively large breasts.

In contrast, RT may be recommended to women with small breasts aiming to increase the probability of long-term breast preservation.

By using these four factors, many low risk DCIS patients can be guided to an informed decision regarding the use of RT after BCS. (40)

\section{Particular Aspects of RT in DCIS}

For patients choosing RT after BCS, the historical standard has been conventional WBRT: 46-50Gy in 23-25 fractions over 5 weeks.

The vast majority of patients treated in the randomized DCIS trials received this type of treatment. Hypofractionated WBRT was used in a subset of patients from RTOG 9804 trial, whereas only $\leq 10 \%$ of the patients in three of the trials received a boost. $(6,52,53)$

\section{Hypofractionation (HF)}

The considerable duration of the treatment associated with the distance from home to the radiotherapy centers and long waiting lists represent matter of inconvenience for the patients.

Hypofractionated whole breast RT (HFWBRT) delivering 40-42.5 Gy in 15-16 fractions given 5 days per week showed equivalence with standard fractionation in terms of local control, disease and overall survival with equivalent or better cosmesis and adverse events profiles for patients with early invasive breast cancer. $(54,55)$

Moreover, it improves patients' convenience, quality of life and is expected to be advantageous in the medical care system by reducing overall costs. (56)

$\mathrm{HF}$ is currently the preferred approach for postoperative breast irradiation in the NCCN guidelines. (9) 
No prospective level 1 evidence exists to support use of HF for the treatment of DCIS, but multiple retrospective studies demonstrated favorable local control when compared to historical controls.

In a multicenter retrospective study from Canada, HF-RT using 42.5 Gy in 16 fractions provides excellent local control for DCIS patients. After a median follow-up time of 4.4 years, 14 patients out of 440 had an ipsilateral local relapse, resulting in a local recurrence free survival of $97 \%$ at 5 years. (57)

In a population based analysis of 1,609 women with DCIS treated with BCS and RT in Ontario from 1994-2003, 60\% received conventional $\mathrm{RT}$ and $40 \%$ received a HF regimen. The 10-year actuarial recurrence free survival rate was $86 \%$ among women treated with conventional RT and $89 \%$ for those treated with HF regimen $(p=0.03)$. Administration of HF-RT was not significantly associated with an increased risk of LR compared to individuals treated with conventional fractionation. (58)

A meta-analysis of observational series including 2,534 patients from 4 retrospective studies found no significant difference in the LR rate between conventional and HF-RT for DCIS; however, a trend for lower recurrence with HF was observed (odds rate 0.78, $\mathrm{p}=0.88$ ). (59)

There is no inherent reason that normal tissue side effects should be different following WBRT for patients with excised DCIS as compared to excised invasive cancer. Therefore, a short RT schedule of 40 Gy in 15 daily fractions on 42.5 Gy in 16 daily fractions should be offered as an option to patients with DCIS. (60)

\section{Role of a Tumor Bed Boost in DCIS}

Following WBRT, many patients receive an additional boost of radiation (i.e. 10-16 Gy in 4-8 fractions) in the region at the highest risk for recurrences.

Patients treated with a boost usually had more risk factors for LR (i.e. young age, positive margins, high grade).

A boost to the tumor bed in addition to the WBRT after BCS significantly reduces LR rates in invasive breast cancer, with the highest benefit for younger patients (61) and is now a standard of care.

Whether this is applicable to patients with pure DCIS is unclear.

Several retrospective studies tried to assess the role of a boost in DCIS, while no prospective randomized study has been published, so far, on this issue.

An international multicenter retrospective study was performed on 373 patients, aged 45 years or less and treated with BCS only (15\%), BCS followed by WBRT (45\%) and BCS and WBRT followed by a boost to the tumor bed (40\%).

A progressive increase of local relapse-free survival at 10 years was observed, starting with BCS only (46\%), to WBRT without boost $(72 \%)$ to WBRT followed by a boost $(86 \%)$ $\mathrm{p}<0.0001$.

In multivariate analysis, the margin status and radiation dose were the only two independent factors for relapse free survival. No difference in overall survival was found. The major advantage correlated with the delivery of the boost was noticed in young women $(\leq 39$ years). (62)

Another study by Wong et al confirmed the favorable effect of the radiation boost with no local recurrence observed among 79 patients receiving a boost, whereas 8 of 141 patients in the "no-boost" group experienced in breast LR after a median follow-up of 46 months (63). These results were obtained despite a higher risk for local recurrence in the boost group (positive or less than $1 \mathrm{~mm}$ margins in $48 \%$ of cases - "boost group" vs 8\% - "no boost group").

Nilsson et al summarized 12 observational studies with a total of 6,943 patients.

There was no statistically significant advantage of an additional boost over WBRT alone after BCS (HR 0.91, p=0.47). However, if only patients with positive margins were included, there was a significant benefit (odds ratio $0.56, p=0.01$ ). (59)

Data from 4,131 cases of DCIS treated in ten academic institutions from the United States, Canada and France were recently reported.(64) 
Eligible patients included those with pure DCIS (i.e. no microinvasion) who received WBRT with or without boost and reached a minimum of 5 years follow-up. Among the 4,131 cases, 2,661 received a radiation boost and 1470 did not.

Median follow-up for all study participants was 9 years.

The ipsilateral breast tumor-free survival for boost vs no boost, respectively, was $97.1 \% \mathrm{vs}$ $96.3 \%$ at 5 years, $94.1 \%$ vs $92.5 \%$ at 10 years and $91.6 \%$ vs $88 \%$ at 15 years following treatment, with these differences achieving statistical significance $(\mathrm{p}=0.013)$.

The authors concluded that the use of a radiation boost provides small but significant long term benefit in reducing breast tumor recurrences for DCIS patients and supports the consideration of DCIS boost in patients undergoing WBRT who have life expectancies of 10 or more years. (64)

\section{Accelerated Partial Breast Irradiation}

Accelerated partial breast irradiation (APBI) is an adjuvant $\mathrm{RT}$ that treats only the lumpectomy cavity plus a small aria surrounding the surgical bed in one week or less. This concept is based upon patterns of failure data demonstrating that the majority of ipsilateral breast failures occur in close proximity to the lumpectomy cavity. $(65,66)$

At this time, APBI can be delivered using brachytherapy techniques (using either the interstitial catheters or the intracavitary device - MammoSite), external beam RT (3D-conformal RT or intensity modulated RT) and intraoperative RT.

Randomized trials and prospective data have demonstrated excellent clinical outcomes and toxicity profiles with this approach in appropriately selected cases. $(67,68,69,70)$

For APBI, the NCCN guidelines recommend a hypofractionated schedule of $34 \mathrm{~Gy}$ divided into 10 fractions delivered twice daily in 5 days for brachytherapy or 38.5 Gy in 10 twice daily fractions with external beam RT to the tumor bed. (9)

In the American Society for Radiation
Oncology (ASTRO) consensus statement on APBI published in 2009, DCIS patients were placed in the cautionary group if the tumor diameter is $\leq 3 \mathrm{~cm}$ and in the unsuitable group if the tumor diameter is $>3 \mathrm{~cm}$. (71)

In the updated ASTRO evidence-based consensus statement, patients with low risk DCIS defined by RTOG 9804 criteria were categorized in the suitable group. (72)

\section{Conclusions}

Adjuvant radiation therapy following breast conserving surgery remains the standard of care for most women with DCIS.

A low-risk group of patients in whom adjuvant RT can be omitted has not been identified so far. A discussion with the patient regarding benefits, risks and limitations of each local treatment is required, because only patients can ultimately decide how much value they place on avoiding recurrences vs inconveniences and adverse effects of RT.

New delivery techniques and altered fractionation schedules currently allow for a reduction in the duration and toxicity, while providing the local control benefit associated with postoperative RT.

\section{References}

1. Lakhani SR, Ellis I0, Schnitt SJ, Tan PH, van de Vijver MJ. WHO Classification of Tumours of the Breast, Fourth Edition. Lyon: IARC Press; 2012.

2. Bleicher RJ. Ductal carcinoma in situ. Surg Clin North Am. 2013; 93(2):393-410.

3. Punglia RS, Schnitt SJ, Weeks JC. Treatment of ductal carcinoma in situ after excision: would a prophylactic paradigm be more appropriate? J Natl Cancer Inst. 2013;105(20):1527-33. doi: 10.1093/ jnci/djt256. Epub 2013 Sep 25.

4. Siegel R, Naishadham D, Jemal A. Cancer statistics 2013. CA Cancer J Clin. 2013;63(1):11-30. doi: 10.3322/caac.21166. Epub 2013 Jan 17.

5. Sanders ME, Schuyler PA, Dupont WD, Page DL. The natural history of low-grade ductal carcinoma in situ of the breast in women treated by biopsy only revealed over 30 years of long-term follow-up. Cancer. 2005;103(12):2481-4.

6. Wapnir IL, Dignam JJ, Fisher B, Mamounas EP, Anderson SJ, Julian $T B$, et al. Long-term outcomes of invasive ipsilateral breast tumor recurrences after lumpectomy in NSABP B-17 and B-24 randomized clinical trials for DCIS. J Natl Cancer Inst. 2011;103(6):478-88. doi: 10.1093/jnci/djr027. Epub 2011 Mar 11.

7. Donker M, Litière S, Werutsky G, Julien JP, Fentiman IS, Agresti R, et al. Breast-conserving treatment with or without radiotherapy in ductal carcinoma In Situ: 15-year recurrence rates and outcome after a recurrence, from the EORTC 10853 randomized phase III trial. J Clin Oncol. 2013;31(32):4054-9. doi: 10.1200/JC0.2013. 
49.5077. Epub 2013 Sep 16.

8. Smith BD. When is good enough really good enough? Defining the role of radiation in low-risk ductal carcinoma in situ. J Clin Oncol. 2015;33(7):686-91. doi: 10.1200/JC0.2014.59.4259. Epub 2015 Jan 20.

9. NCCN Clinical Practice Guidelines in Oncology, Breast Cancer, v.2.2016. 2016. National Comprehensive Cancer Network.

10. Hwang ES. The impact of surgery on ductal carcinoma in situ outcomes: the use of mastectomy. J Natl Cancer Inst Monogr. 2010;2010(41):197-9. doi: 10.1093/jncimonographs/lgq032.

11. Baxter NN, Virnig BA, Durham SB, Tuttle TM. Trends in the treatment of ductal carcinoma in situ of the breast. J Natl Cancer Inst. 2004; 96(6):443-8.

12. Burstein HJ, Polyak K, Wong JS, Lester SC, Kaelin CM. Ductal carcinoma in situ of the breast. N Engl J Med. 2004;350(14):1430-41.

13. Cutuli B, Lemanski C, Fourquet A, de Lafontan B, Giard S, Meunier A, et al. Breast-conserving surgery with or without radiotherapy vs mastectomy for ductal carcinoma in situ: French Survey experience. Br J Cancer. 2009;100(7):1048-54. doi: 10.1038/sj.bjc.6604968. Epub 2009 Mar 10.

14. Wärnberg F, Garmo H, Emdin S, Hedberg V, Adwall L, Sandelin K, et al. Effect of radiotherapy after breast-conserving surgery for ductal carcinoma in situ: 20 years follow-up in the randomized SweDCIS Trial. J Clin Oncol. 2014;32(32):3613-8.

15. Cuzick J, Sestak I, Pinder SE, Ellis IO, Forsyth S, Bundred NJ, et al. Effect of tamoxifen and radiotherapy in women with locally excised ductal carcinoma in situ: long-term results from the UK/ANZ DCIS trial. Lancet Oncol. 2011;12(1):21-9. doi: 10.1016/S14702045(10)70266-7. Epub 2010 Dec 7.

16. Early Breast Cancer Trialists' Collaborative Group (EBCTCG), Correa C, McGale P, Taylor C, Wang Y, Clarke M, Davies C, et al. Overview of the randomized trials of radiotherapy in ductal carcinoma in situ of the breast. J Natl Cancer Inst Monogr. 2010;2010(41):162-77. doi: 10.1093/jncimonographs/lgg039.

17. Solin LJ. The impact of adding radiation treatment after breast conservation surgery for ductal carcinoma in situ of the breast. $J$ Natl Cancer Inst Monogr. 2010;2010(41):187-92. doi: 10.1093 /jncimonographs/lgq020.

18. Clarke M, Collins R, Darby S, Davies C, Elphinstone P, Evans V, et al. Effects of radiotherapy and of differences in the extent of surgery for early breast cancer on local recurrence and 15-year survival: an overview of the randomised trials. Lancet. 2005; 366(9503):2087-106.

19. Silverstein MJ. Ductal carcinoma in situ of the breast: 11 reasons to consider treatment with excision alone. Womens Health (Lond). 2008;4(6):565-77. doi: 10.2217/17455057.4.6.565.

20. Lagios MD, Page DL, Silverstein MJ. Prospective study of wide excision alone for ductal carcinoma in situ of the breast. J Clin Oncol. 2006;24(23):3809-11; author reply 3811-2.

21. Silverstein MJ. Not everyone with ductal carcinoma in situ of the breast treated with breast preservation needs post-excisional radiation therapy. Breast. 2000;9(4):189-93.

22. Recht A. Are the randomized trials of radiation therapy for ductal carcinoma in situ still relevant? J Clin Oncol. 2014;32(32):3588-90. doi: 10.1200/JC0.2014.58.1066. Epub 2014 Oct 13.

23. Mokbel K, Cutuli B. Heterogeneity of ductal carcinoma in situ and its effects on management. Lancet Oncol. 2006;7(9):756-65.

24. Cutuli B, Bernier J, Poortmans P. Radiotherapy in DCIS, an underestimated benefit? Radiother Oncol. 2014;112(1):1-8. doi: 10.1016/ j.radonc.2014.06.011. Epub 2014 Jul 5.

25. Allred DC. Ductal carcinoma in situ: terminology, classification, and natural history. J Natl Cancer Inst Monogr. 2010;2010(41):134-8. doi: 10.1093/jncimonographs/lgq035.

26. Alvarado R, Lari SA, Roses RE, Smith BD, Yang W, Mittendorf EA, et al. Biology, treatment, and outcome in very young and older women with DCIS. Ann Surg Oncol. 2012;19(12):3777-84. doi: 10.1245/s10434-012-2413-4. Epub 2012 May 24.
27. Shamliyan T, Wang SY, Virnig BA, Tuttle TM, Kane RL. Association between patient and tumor characteristics with clinical outcomes in women with ductal carcinoma in situ. J Natl Cancer Inst Monogr. 2010;2010(41):121-9. doi: 10.1093/jncimonographs/lgq034.

28. Solin LJ, Fourquet A, Vicini FA, Taylor M, Olivotto IA, Haffty B, et al. Long-term outcome after breast-conservation treatment with radiation for mammographically detected ductal carcinoma in situ of the breast. Cancer. 2005;103(6):1137-46.

29. EORTC Breast Cancer Cooperative Group1; EORTC Radiotherapy Group, Bijker N, Meijnen P, Peterse JL, Bogaerts J, Van Hoorebeeck I, Julien JP, et al. Breast-conserving treatment with or without radiotherapy in ductal carcinoma-in-situ: ten-year results of European Organisation for Research and Treatment of Cancer randomized phase III trial 10853--a study by the EORTC Breast Cancer Cooperative Group and EORTC Radiotherapy Group. J Clin Oncol. 2006;24(21):3381-7. Epub 2006 Jun 26.

30. Morrow M, Jagsi R, Alderman AK, Griggs JJ, Hawley ST, Hamilton AS, et al. Surgeon recommendations and receipt of mastectomy for treatment of breast cancer. JAMA. 2009;302(14):1551-6. doi: 10.1001/jama.2009.1450.

31. King TA, Sakr R, Patil S, Gurevich I, Stempel M, Sampson M, et al. Clinical management factors contribute to the decision for contralateral prophylactic mastectomy. J Clin Oncol. 2011;29(16):2158-64. doi: 10.1200/JC0.2010.29.4041. Epub 2011 Apr 4.

32. Morrow M, Van Zee KJ, Solin LJ, Houssami N, Chavez-MacGregor M, Harris JR, et al. Society of Surgical Oncology-American Society for Radiation Oncology-American Society of Clinical Oncology Consensus Guideline on Margins for Breast-Conserving Surgery With Whole-Breast Irradiation in Ductal Carcinoma in Situ. Pract Radiat Oncol. 2016;6(5):287-95. doi: 10.1016/j.prro.2016.06.011. Epub 2016 Jun 24.

33. Kerlikowske K. Epidemiology of ductal carcinoma in situ. J Natl Cancer Inst Monogr. 2010;2010(41):139-41. doi: 10.1093/jncimonographs/lgq027.

34. Shapiro CL, Recht A. Side effects of adjuvant treatment of breast cancer. N Engl J Med. 2001;344(26):1997-2008.

35. Solin LJ, Gray R, Hughes LL, Wood WC, Lowen MA, Badve SS, et al. Surgical Excision Without Radiation for Ductal Carcinoma in Situ of the Breast: 12-Year Results From the ECOG-ACRIN E5194 Study. J Clin Oncol. 2015;33(33):3938-44. doi: 10.1200/JCO. 2015.60.8588. Epub 2015 Sep 14

36. Silverstein MJ, Lagios MD, Craig PH, Waisman JR, Lewinsky BS, Colburn WJ, et al. A prognostic index for ductal carcinoma in situ of the breast. Cancer. 1996;77(11):2267-74.

37. Silverstein MJ. The University of Southern California/Van Nuys prognostic index for ductal carcinoma in situ of the breast. Am J Surg. 2003;186(4):337-43.

38. de Mascarel I, Bonichon F, MacGrogan G, de Lara CT, Avril A, Picot V, et al. Application of the van nuys prognostic index in a retrospective series of 367 ductal carcinomas in situ of the breast examined by serial macroscopic sectioning: practical considerations. Breast Cancer Res Treat. 2000;61(2):151-9.

39. MacAusland SG, Hepel JT, Chong FK, Galper SL, Gass JS, Ruthazer $R$, et al. An attempt to independently verify the utility of the Van Nuys Prognostic Index for ductal carcinoma in situ. Cancer. 2007; 110(12):2648-53

40. Smith BD. When is good enough really good enough? Defining the role of radiation in low-risk ductal carcinoma in situ. J Clin Oncol. 2015;33(7):686-91. doi: 10.1200/JC0.2014.59.4259. Epub 2015 Jan 20.

41. McCormick B, Winter K, Hudis C, Kuerer HM, Rakovitch E, Smith $\mathrm{BL}$, et al. RTOG 9804: a prospective randomized trial for good-risk ductal carcinoma in situ comparing radiotherapy with observation. J Clin Oncol. 2015;33(7):709-15. doi: 10.1200/JC0.2014.57.9029. Epub 2015 Jan 20.

42. Wong JS, Chen YH, Gadd MA, Gelman R, Lester SC, Schnitt SJ, et al. Eight-year update of a prospective study of wide excision alone 
for small low- or intermediate-grade ductal carcinoma in situ (DCIS). Breast Cancer Res Treat. 2014;143(2):343-50. doi: 10.1007/s10549-013-2813-6. Epub 2013 Dec 18.

43. Solin LJ, Gray R, Baehner FL, Butler SM, Hughes LL, Yoshizawa C et al. A multigene expression assay to predict local recurrence risk for ductal carcinoma in situ of the breast. J Natl Cancer Inst. 2013; 105(10):701-10. doi: 10.1093/jnci/djt067. Epub 2013 May 2.

44. Rakovitch E, Nofech-Mozes S, Hanna W, Baehner FL, Saskin R, Butler SM, et al. A population-based validation study of the DCIS Score predicting recurrence risk in individuals treated by breastconserving surgery alone. Breast Cancer Res Treat. 2015;152(2): 389-98. doi: 10.1007/s10549-015-3464-6. Epub 2015 Jun 29.

45. Raldow AC, Sher D, Chen AB, Recht A, Punglia RS. Cost Effectiveness of the Oncotype DX DCIS Score for Guiding Treatment of Patients With Ductal Carcinoma In Situ. J Clin Oncol. 2016 Sep 12. pii: JC0678532. [Epub ahead of print]

46. Pignol JP, Olivotto I, Rakovitch E, Gardner S, Sixel K, Beckham W, et al. A multicenter randomized trial of breast intensity-modulated radiation therapy to reduce acute radiation dermatitis. J Clin Oncol. 2008;26(13):2085-92. doi: 10.1200/JC0.2007.15.2488. Epub 2008 Feb 19

47. Donovan E, Bleakley N, Denholm E, Evans P, Gothard L, Hanson J, et al. Randomised trial of standard 2D radiotherapy (RT) versus intensity modulated radiotherapy (IMRT) in patients prescribed breast radiotherapy. Radiother Oncol. 2007;82(3):254-64. Epub 2007 Jan 16.

48. Partridge A, Adloff K, Blood E, Dees EC, Kaelin C, Golshan M, et al. Risk perceptions and psychosocial outcomes of women with ductal carcinoma in situ: Iongitudinal results from a cohort study. J Natl Cancer Inst. 2008;100(4):243-51. doi: 10.1093/jnci/djn010. Epub 2008 Feb 12.

49. Rakovitch E, Franssen E, Kim J, Ackerman I, Pignol JP, Paszat L, et al. A comparison of risk perception and psychological morbidity in women with ductal carcinoma in situ and early invasive breast cancer. Breast Cancer Res Treat. 2003;77(3):285-93.

50. van Gestel YR, Voogd AC, Vingerhoets AJ, Mols F, Nieuwenhuijzen $\mathrm{GA}$, van Driel $0 \mathrm{~J}$, et al. A comparison of quality of life, disease impact and risk perception in women with invasive breast cancer and ductal carcinoma in situ. Eur J Cancer. 2007;43(3):549-56. Epub 2006 Nov 30 .

51. Morrow M, Katz SJ. Addressing Overtreatment in DCIS: What Should Physicians Do Now? J Natl Cancer Inst. 2015;107(12): djv290. doi: 10.1093/jnci/djv290. Print 2015 Dec.

52. Julien JP, Bijker N, Fentiman IS, Peterse JL, Delledonne V, Rouanet P, et al. Radiotherapy in breast-conserving treatment for ductal carcinoma in situ: first results of the EORTC randomised phase III tria 10853. EORTC Breast Cancer Cooperative Group and EORTC Radiotherapy Group. Lancet. 2000;355(9203):528-33.

53. Emdin SO, Granstrand B, Ringberg A, Sandelin K, Arnesson LG, Nordgren $\mathrm{H}$, et al. SweDCIS: Radiotherapy after sector resection for ductal carcinoma in situ of the breast. Results of a randomised trial in a population offered mammography screening. Acta Oncol. 2006;45(5):536-43.

54. Whelan TJ, Pignol JP, Levine MN, Julian JA, MacKenzie R, Parpia S, et al. Long-term results of hypofractionated radiation therapy for breast cancer. N Engl J Med. 2010;362(6):513-20. doi: 10.1056/ NEJMoa0906260.

55. Haviland JS, Owen JR, Dewar JA, Agrawal RK, Barrett J, Barrett-Lee PJ, et al. The UK Standardisation of Breast Radiotherapy (START) trials of radiotherapy hypofractionation for treatment of early breast cancer: 10-year follow-up results of two randomised controlled trials. Lancet Oncol. 2013:14(11):1086-94. doi: 10.1016 /S14702045(13)70386-3. Epub 2013 Sep 19

56. Kim KS, Shin KH, Choi N, Lee SW. Hypofractionated whole breast irradiation: new standard in early breast cancer after breastconserving surgery. Radiat Oncol J. 2016;34(2):81-7. doi: 10.3857 /roj.2016.01697. Epub 2016 Jun 17.

57. Hathout L, Hijal T, Théberge V, Fortin B, Vulpe H, Hogue JC, et al. Hypofractionated radiation therapy for breast ductal carcinoma in situ.
Int J Radiat Oncol Biol Phys. 2013;87(5):1058-63. doi: 10.1016/j.ijrobp.2013.08.026. Epub 2013 Oct 8.

58. Lalani N, Paszat L, Sutradhar R, Thiruchelvam D, Nofech-Mozes S, Hanna W, et al. Long-term outcomes of hypofractionation versus conventional radiation therapy after breast-conserving surgery for ductal carcinoma in situ of the breast. Int J Radiat Oncol Biol Phys. 2014;90(5):1017-24. doi: 10.1016/j.ijrobp.2014.07.026. Epub 2014 Sep 11.

59. Nilsson C, Valachis A. The role of boost and hypofractionation as adjuvant radiotherapy in patients with DCIS: a meta-analysis of observational studies. Radiother Oncol. 2015;114(1):50-5. doi: 10.1016/ j.radonc.2015.01.001. Epub 2015 Jan 14.

60. Koulis TA, Phan T, Olivotto IA. Hypofractionated whole breast radiotherapy: current perspectives. Breast Cancer (Dove Med Press). 2015;7:363-70. doi: 10.2147/BCTT.S81710. eCollection 2015.

61. Bartelink H, Maingon P, Poortmans P, Weltens C, Fourquet A, Jager J, et al. Whole-breast irradiation with or without a boost for patients treated with breast-conserving surgery for early breast cancer: 20year follow-up of a randomised phase 3 trial. Lancet Oncol. 2015;16(1):47-56. doi: 10.1016/S1470-2045(14)71156-8. Epub 2014 Dec 9.

62. Omlin A, Amichetti M, Azria D, Cole BF, Fourneret P, Poortmans P, et al. Boost radiotherapy in young women with ductal carcinoma in situ: a multicentre, retrospective study of the Rare Cancer Network. Lancet Oncol. 2006;7(8):652-6.

63. Wong P, Lambert C, Agnihotram RV, David M, Duclos M, Freeman CR. Ductal carcinoma in situ--the influence of the radiotherapy boost on local control. Int J Radiat Oncol Biol Phys. 2012; 82(2):e153-8. doi: 10.1016/j.jirobp.2011.03.045. Epub 2011 Jun 12.

64. Moran MS, Zhao Y, Ma S, Kirova YM, Fourquet A, Chen PY, et al. Truong. Radiation Boost for Ductal Carcinoma In Situ After WholeBreast Radiation Therapy (WBRT) Improves Local Control: Analysis From 10 Pooled Academic Institutions. Int J Radiat Oncol Biol Phys. 2016 Oct 1;96(2) Suppl: S144.

65. Gage I, Recht A, Gelman R, Nixon AJ, Silver B, Bornstein BA, et al. Long-term outcome following breast-conserving surgery and radiation therapy. Int J Radiat Oncol Biol Phys. 1995;33(2):245-51.

66. Swanson TA, Vicini FA. Overview of accelerated partial breast irradiation. Curr Oncol Rep. 2008;10(1):54-60.

67. Polgár C, Fodor J, Major T, Sulyok Z, Kásler M. Breast-conserving therapy with partial or whole breast irradiation: tenyear results of the Budapest randomized trial. Radiother Oncol. 2013;108(2):197-202. doi: 10.1016/j.radonc.2013.05.008. Epub 2013 Jun 3.

68. Polgár C, Major T, Fodor J, Sulyok Z, Somogyi A, Lövey K, et al. Accelerated partial-breast irradiation using high-dose-rate interstitial brachytherapy: 12-year update of a prospective clinical study. Radiother Oncol. 2010;94(3):274-9. doi: 10.1016/j.radonc.2010.01. 019. Epub 2010 Feb 22

69. Strnad V, Ott OJ, Hildebrandt G, Kauer-Dorner D, Knauerhase H, Major T, et al. 5-year results of accelerated partial breast irradiation using sole interstitial multicatheter brachytherapy versus wholebreast irradiation with boost after breast-conserving surgery for lowrisk invasive and in-situ carcinoma of the female breast: a randomised, phase 3, non-inferiority trial. Lancet. 2016;387(10015): 229-38.

70. Livi L, Meattini I, Marrazzo L, Simontacchi G, Pallotta S, Saieva C, et al. Accelerated partial breast irradiation using intensity-modulated radiotherapy versus whole breast irradiation: 5-year survival analysis of a phase 3 randomised controlled trial. Eur J Cancer. 2015;51(4): 451-63.

71. Smith BD, Arthur DW, Buchholz TA, Haffty BG, Hahn CA, Hardenbergh $\mathrm{PH}$, et al. Accelerated partial breast irradiation consensus statement from the American Society for Radiation Oncology (ASTRO). Int J RadiatOncolBiol Phys. 2009;74(4):987-1001.

72. Correa C, Harris EE, Leonardi MC, Smith BD, Taghian AG, Thompson AM, et al. Accelerated Partial Breast Irradiation: Executive summary for theupdate of an ASTRO Evidence-Based Consensus Statement. Pract Radiat Oncol. 2016. pii: S1879-8500(16)30184-9. 